\title{
The Active Reef Restoration Toolbox is a Vehicle for Coral Resilience and Adaptation in a Changing World
}

\section{Baruch Rinkevich $\mathbb{D}$}

Israel Oceanography \& Limnological Research, National institute of Oceanography, Tel Shikmona, P.O. Box 8030, Haifa 31080, Israel; buki@ocean.org.il; Tel.: +972-4-856-5275; Fax: +972-4-851-1911

Received: 23 May 2019; Accepted: 25 June 2019; Published: 28 June 2019

\begin{abstract}
The accelerating marks of climate change on coral-reef ecosystems, combined with the recognition that traditional management measures are not efficient enough to cope with climate change tempo and human footprints, have raised a need for new approaches to reef restoration. The most widely used approach is the "coral gardening" tenet; an active reef restoration tactic based on principles, concepts, and theories used in silviculture. During the relatively short period since its inception, the gardening approach has been tested globally in a wide range of reef sites, and on about 100 coral species, utilizing hundreds of thousands of nursery-raised coral colonies. While still lacking credibility for simulating restoration scenarios under forecasted climate change impacts, and with a limited adaptation toolkit used in the gardening approach, it is still deficient. Therefore, novel restoration avenues have recently been suggested and devised, and some have already been tested, primarily in the laboratory. Here, I describe seven classes of such novel avenues and tools, which include the improved gardening methodologies, ecological engineering approaches, assisted migration/colonization, assisted genetics/evolution, assisted microbiome, coral epigenetics, and coral chimerism. These are further classified into three operation levels, each dependent on the success of the former level. Altogether, the seven approaches and the three operation levels represent a unified active reef restoration toolbox, under the umbrella of the gardening tenet, focusing on the enhancement of coral resilience and adaptation in a changing world.
\end{abstract}

Keywords: climate change; reef restoration; gardening; ecological engineering; assisted migration/colonization; assisted genetics/evolution; assisted microbiome; epigenetics; chimerism

\section{Introduction}

Decades of continuous and substantial global climate change impacts, together with accumulated anthropogenic footprints on coral reefs, have demonstrated that, excluding a few remote reef sites, all major reefs suffer from accrued degradation, and a complete reshuffling of their biological diversity as they transform into less diverse ecosystems [1-3]. The abundance of corals and reef dwelling organisms has been impacted by escalating pressures and is continuously diminishing, while goods and services are failing [3] and biodiversity diminishes at ever growing rates, which are currently at $0.5-2 \%$ per year $[4,5]$. Climate change drives ocean warming and acidification, impacts overall physiological traits, triggers large-scale coral bleaching events, fuels tropical storms [6], slows reef calcification and growth, and impairs natural recruitment [7]. Moreover, devastating impacts are rapidly increasing in scale and intensity, bringing coral reefs to heightened eroded states globally, and affecting a decline in their ecological resilience capacities and adaptation to changing climate conditions. Globally, coral reef communities will most likely be in a state of flux for years to come (as many are already in), driven by different climate change drivers [8] with multiple stressors that act in tandem [9] and increase the risk of phase shifts into algal dominated reefs. Only a few reef sites exhibit some resistance to global climate change drivers [10]. 
As in other marine and terrestrial ecosystems, the rates of impact of climate change on species and populations are accelerating worldwide, calling for new forms of intervention. Furthermore, with the recognition that traditional measures (such as the creation of MPAs, reducing specific anthropogenic impacts, etc.) are not sufficient to cope with the combination of climate change/human footprints $[4,11-13]$ the gloomy status of global reef ecosystems ignited the need for novel approaches that may accurately offset and mitigate the destructive impacts of global climate change, with alternative effective reef management and reef rehabilitation approaches. The initial idea was that these new approaches would be used to complement conservation efforts, allowing current reefs to provide ecosystem services under a range of future environmental conditions.

Probably the most effective among the emerging ideas, and the most widely used method, is the "gardening" approach for active reef restoration. This approach is based on 'principles', concepts and theories used in silviculture [13-19]. Taking into consideration coral reefs' inability to naturally recuperate without human intervention, the "gardening" concept, a fully employed active reef restoration, is a two-step process (the nursery phase dedicated to the development of large stocks of coral colonies in mid-water floating nurseries, followed by the transplantation phase where nursery-farmed coral colonies, which have reached suitable sizes, are out-planted onto degraded reef areas). The active "gardening" concept has emerged as an effective method [20], replacing the former less successful restoration approaches that focused on transplantation of coral colonies from a donor site onto a damaged site $[13,21]$.

The terms 'active' and 'passive' restoration originated from forestation practices, which reflect two disparate broad categories [22]. 'Active' restoration is where human surrogate activities and practices directly help ecosystems recuperate or improve their state, while 'passive' restoration is when no human intervention is taken upon the reefs themselves, instead it focuses on reducing/eliminating anthropogenic impacts, allowing natural recuperation to lead the way to recovery $[22,23]$. One of the major benefits of active restoration is its critical role in reversing trajectories in ecosystems that are caught in dilapidated states [20,24]. Following this underlying principle, all key successful approaches for reef restoration (Table 1) use the 'active restoration' tactic, some of which harness natural processes such as assisted migration, epigenetics and coral chimerism (Table 1).

Table 1. The seven major research avenues added to the gardening approach for the creation of a climate adaptation toolkit (chosen references from the literature).

\begin{tabular}{|c|c|c|}
\hline Avenue & Types of Coral Adaptation & Citations \\
\hline $\begin{array}{l}\text { Ecological } \\
\text { engineering }\end{array}$ & $\begin{array}{l}\text { Use of herbivorous fish/invertebrates for improved nursery } \\
\text { maintenance; animal-assisted cleaning; engineering of larval supply } \\
\text { through transplantation of nursery-farmed gravid colonies; } \\
\text { transplantation of ecological engineering species; development of larval } \\
\text { hubs and 'artificial spawning hotspots'; tiling the reef; nubbin fusions } \\
\text { for enlarged colonies; micro-fragmentation; serially positioning } \\
\text { nurseries to create new mid-water coral biological corridors through } \\
\text { stepping stone mechanisms; using dietary habits of grazers as biological } \\
\text { controls of fouling macroalgae; large scale restoration acts; enhanced } \\
\text { calcification/survival rates via seawater electrolysis. }\end{array}$ & {$[1,25-28,32,39,45-61]$} \\
\hline $\begin{array}{c}\text { Assisted } \\
\text { migration/colonization }\end{array}$ & $\begin{array}{l}\text { Moving species outside their historic ranges may mitigate loss of } \\
\text { biodiversity in the face of global climate change. }\end{array}$ & {$[62-64]$} \\
\hline
\end{tabular}


Table 1. Cont.

\begin{tabular}{|c|c|c|}
\hline Avenue & Types of Coral Adaptation & Citations \\
\hline Assisted microbiome & $\begin{array}{l}\text { Adaptation by changing bacterial communities living in tissues, mucus } \\
\text { layers and substrates to settle at the shortest timeframe of days/weeks; } \\
\text { coral "microbial-therapy" and microbiome inoculation; improved } \\
\text { nutrient cycles; contributing to coral host tolerance of thermal stress. }\end{array}$ & {$[72-75]$} \\
\hline Epigenetics & $\begin{array}{l}\text { Creation of novel alleles and traits that can better withstand } \\
\text { environmental changes; developing resistance towards adverse } \\
\text { conditions. }\end{array}$ & {$[46,76-83]$} \\
\hline Chimerism & $\begin{array}{l}\text { Enhanced growth and survival of spat/small colonies; countering the } \\
\text { erosion of genetic and phenotypic diversity; high flexibility of chimeric } \\
\text { entities on somatic constituents following changes in environmental } \\
\text { conditions; the chimera synergistically presents the best-fitting } \\
\text { combination of genetic components to environmental challenges; } \\
\text { facilitating the healing of exposed coral skeletons }\end{array}$ & [84-91] \\
\hline
\end{tabular}

Since the short period that has elapsed since its inception, the employment of the gardening approach in a wide range of reef sites worldwide, has by now earned its credentials for (a) farming coral colonies from a large number of coral species ( ca 100) in mid-water nurseries, including massive, branching and encrusting forms; (b) establishing unlimited stocks of coral colonies in underwater nurseries; (c) the successful transplantation off nursery farmed coral colonies onto denuded reef areas, and (d) ensuring the low cost of farming and transplanting coral colonies [1,17]. However, this approach still lacks credibility in simulating restoration scenarios and trajectories that target specific goals. As such, additional restoration approaches were suggested and some have already been tested (Table 1), altogether creating a novel active reef restoration toolbox. Here, I'll summarize some of the major aspects and the hierarchy of these reef restoration avenues and approaches, which form the first toolbox to be used for enhancing coral resilience and coral adaptation in a changing world.

\section{Defining the Toolbox}

While active reef restoration techniques and their underlying fundamental principles are still under development, this discipline is challenged by the realization that reefs are already in transition, driven by differential species responses to environmental change, and that corals in the 'reef of tomorrow' should adapt to altering environmental conditions. The above infers that current basic methods for reef restoration are still insufficient to secure a future for coral reefs. This has prompted a surge in active restoration initiatives that can be divided into seven major research avenues added to the gardening approach (Table 1); each avenue is formulated in such a way as to guide an effective reef restoration tactic. Together they form a new reef restoration toolkit.

\subsection{Improved Gardening Methodologies}

As coral transplants show improved survival the larger they become, the early notion guiding the gardening approach was to develop coral colonies to a size that will significantly reduce mortality at transplantation sites. The midwater floating nurseries allow reduced competition for resources (substrate, light), better protection against predation pressures, provide improved conditions for reduced sedimentation and continuously increased water flow conditions for improved nutrition [26-28]. The working rationale has favored the demand for low-cost, low-tech reef restoration methodologies, with simple technical requirements that could be ubiquitously implemented anywhere worldwide [13-16,21]. This however is not sufficiently satisfactory, and the basic techniques that have been developed to maximize coral survival and productivity were supplemented by 
additional methodologies and technical approaches, all bundled under the title of 'improved gardening methodologies' (Table 1).

The literature in Table 1 reveals examples from a wide ranging, and continuously increasing, list of technological advancements, on almost every aspect of the coral gardening approach. This includes the development of various nursery types, adapted for a wide range of needs (such as the regular 'bed' nursery, the rope nursery, depth-adjustable nursery, nursery housing stock of large colonies, the larval dispersion hub nursery, and more (Figure 1) [1,26-28,45,46]; enhanced efficiencies for nursery maintenance, sustainability and yields (such as improved maintenance, harnessing herbivory by fishes and invertebrates as a parameter for positive maintenance feedbacks; spat feeding in ex situ nurseries for enhanced growth/survival; improved nursery maintenance by using environmentally friendly antifouling; caging for recently settled spat-to enhance early post-settlement survival; the use of coral fragments that lack polyps; the increasing stocks of larvae from brooding coral species; techniques for the improved survival of coral propagules), and more. The same goes for the transplantation phase, that has been augmented with improved methodologies, such as the development of different attachment procedures, improving coral self-attachment to substrates, clustering transplants for improved growth/survival outcomes, choosing favorable/improved substrates and coating materials, improved seeding approaches for enhanced settlement and early post-settlement survival, new seeding methodologies, augmenting post-transplantation growth and survival of juveniles via nutritional enhancement, maintaining/enhancing genotypic diversity, and more. While not yet tested for direct resilience and adaptation, the accumulated results suggest that improved gardening protocols not only enhance growth and survival at the nursery stage, but may have additional impacts on growth, survival and reproduction for years post-transplantation (e.g., [39,46,47]).
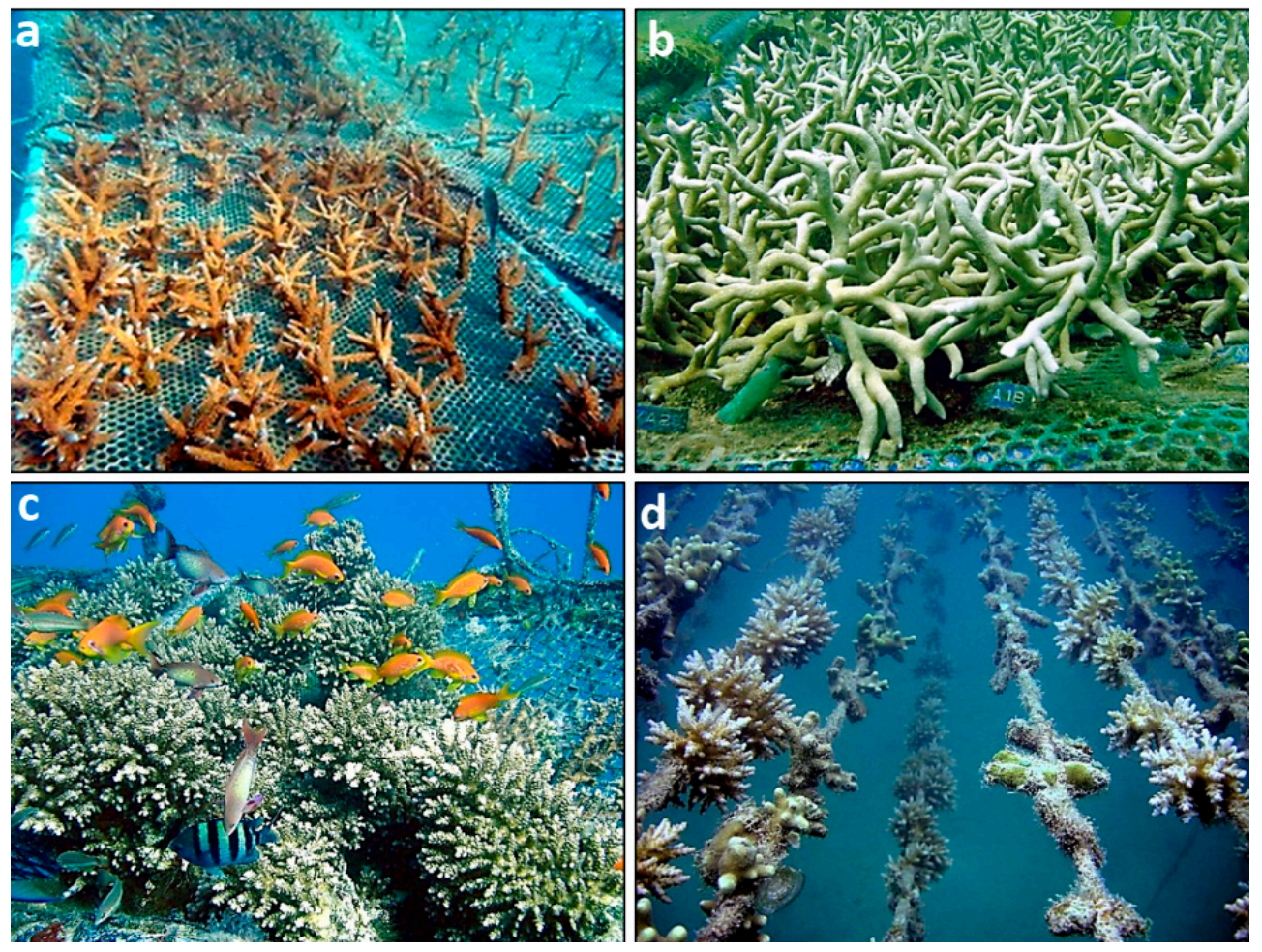

Figure 1. Three types of midwater floating nurseries, the first step of the "gardening" tenet. Nurseries are adapted for various transplantation needs and practices. $(\mathbf{a}, \mathbf{b})$, the regular 'bed' nursery, where corals (usually mono-species cultures) are directly farmed on the nursery base. (a) a short period after inception, where most of the mesh-base of the nursery is still seen (Acropora formosa, Bolinao, the Philippines). (b) a 'bed' nursery completely covered with Montipora digitata colonies (Bolinao, the Philippines). (c) a classical floating nursery. The nursery substrate is made of a rope net (sized $10 \times 10 \mathrm{~m}$ ). Coral nubbins 
are glued onto plastic pins ( $9 \mathrm{~cm}$ long, $0.3-0.6 \mathrm{~cm}$ wide leg, and $2 \mathrm{~cm}$ diameter "head") and are inserted into plastic nets stretched over PVC frames $(30 \times 50 \mathrm{~cm})$. Frames with corals are tied to the nursery substrate (Eilat, Israel). This type of nursery allows for a pre-planned transplantation protocol, where each coral colony has its own 'pot' (the plastic pin) and the transplantation protocol considers the attached pin, with limited stress to the growing coral. An established nursery attracts fish and reef associated invertebrates recruited from the plankton. (d) Rope nursery (Bolinao, the Philippines). This nursery accommodates small coral fragments inserted within the rope threads, creating an easily constructed nursery bed that is transplanted together with the developing corals. Photos: $a, b, d=G$. Levy, c $=$ S. Shafir.

\subsection{Ecological Engineering}

Ecological engineering is defined as: "the design of sustainable ecosystems that integrate human society with its natural environment for the benefit of both" [92]. It involves not only the restoration of ecosystems that have been noticeably altered by either anthropogenic impacts and/or global climate change drivers, but also reflects the emerging scientific discipline that is associated with the development of sustainable new and/or hybrid ecosystems, which have human and ecological significance, providing (when possible) equivalent levels of goods and services as the original ecosystems.

As noted earlier [17] the active gardening approach can be regarded as a ubiquitous ecological engineering platform for reef restoration measures performed on a global scale, having properties that incorporate ecological engineering aspects and tools under a common scientific umbrella (e.g., [39,46,47,84]), including the use of species (corals, fish, other invertebrates) that are allogenic and autogenic ecosystem engineers. This is of specific importance since climate change drivers may hinder the ecological engineering capacities of scleractinian corals as primary reef ecosystem engineers [93]. Clearly, this requires a comprehensive understanding of the engineering capabilities that may be associated with reef restoration approaches, and of the ways ecological engineering species function as reef ecosystem engineers.

Both scientific notions, 'ecological engineering' and 'ecosystem restoration', while representing distinct disciplines [94], are widely used together in terrestrial environments to repair a number of deterioration scenarios [92,94,95]. While 'ecological engineering' provides more predictable outcomes with higher functionalities associated with the chosen ecosystem services, 'ecological restoration' tends to produce higher diversity outcomes, which are aimed at long-term recovery of lost ecosystem services. Principles of both disciplines are primarily intermingled in large scale restoration efforts [94]. Focusing on coral reef ecosystems, ecological engineering tactics, together with restoration of degraded reef habitats, are increasingly recognized as valuable tools, primarily in association with the gardening approach [17,21,39,46,47,84]. It has been also suggested [47] that integrating functional considerations into transplantation acts, such as in the use of allogenic and autogenic engineer species, could improve the impacts of restoration on reef biodiversity.

The literature in Table 1 offers examples from the wide-ranging and increasing number of ecological engineering approaches, covering various aspects of the coral gardening tenet. The prevailing belief predicts that herbivory by fishes and invertebrates (primarily sea urchins and gastropods) is the cornerstone of the developed complex ecological networks that suppress macroalgal cover, minimize coral-algal competition, increasing coral growth and recruitment and dictating coral-dominated reefs' health levels. As a result, much attention has been devoted to the use of herbivorous organisms for improved nursery maintenance, for animal-assisted cleaning and for adapting dietary habits of grazers as biological controls of fouling macroalgae in coral nurseries [25-27,61]. As a matter of fact, in the Eilat (Red Sea) nursery, herbivores like the fish Siganus rivulatus and the sea urchin Diadema setosum controlled algal growth by virtue of intensive grazing [25]. This becomes even more relevant with the forecasted global climate change impacts on grazing kernels (e.g., [96]). In the same way, coralivorous 
species in the Eilat nursery [28] could be effectively eliminated by a top down control reliant on fish predation (mainly Thalassoma rueppellii and T. lunare).

The recently developed ecological engineering approaches are also engaged in various reproductive activities and planula larvae aspects. Examples are the engineering of larval supply through transplantation of nursery-farmed gravid colonies [46], the establishment of coral nurseries as larval dispersion hubs and as 'artificial spawning hotspots' [1,17,44,47,97], and the enhancement of larval survival/growth under nursery conditions $[32,33,58]$. Several entire-reef ecological engineering aspects involved are for example: the selection of coral species for reef restoration while considering their autogenic/allogenic engineering properties [39], serially positioning nurseries to create novel mid-water biological corridors for larval recruitment through stepping stone mechanisms [17], enhancing calcification and survival rates through electrolysis in seawater [48-50], micro-fragmentation of coral colonies for various purposes such as tiling the reefs, and the creation of large colonies within short time periods $[53,59,60]$ versus nubbins/spat fusions for enlarged colonies $[53,84]$, and more. All the above mentioned may enhance efficiency rates of the gardening restoration approach in combating the impacts of global climate change [98].

\subsection{Assisted Migration/Colonization}

Climate change is causing spatial-temporal shifts in environmental conditions, challenging species that are unable to relocate to suitable environments, thus increasing their risk of extinction. Human directed (Table 1) and natural movements of coral species outside their historic ranges ('assisted migration/colonization' and 'natural range expansion', respectively) into more favorable sites, may mitigate the loss of biodiversity in the face of global climate change [62]. Indeed, natural poleward range expansion of corals has been widely documented, from recent fossil records where Acropora-dominated reefs extended along the Florida coast as far north as Palm Beach County [99] and from Australian Pleistocene reefs [100], to the last 80 years of national records from Japanese temperate areas, where key reef formation species revealed speeding poleward range expansions of up to $14 \mathrm{~km} /$ year $[101,102]$ and to coral species range extensions in the Eastern and Western Australian coasts $[103,104]$. While these and other studies support the notion that gradual warming seems to drive range extensions of tropical reef fauna into temperate areas, other studies [105] noted that the dose of photosynthetically available radiation over winter can severely constrain such latitudinal coral habitat expansions.

As for assisted migration/colonization, this conservation strategy has been considered not only for the relocation of species, populations, genotypes, and/or phenotypes to sites beyond their historical distribution, but also for species whose ranges have become highly fragmented [62]. While some studies suggest that assisted colonization is viable due to the introduction of novel, and/or relaxed selection, such operations may lead to an unintended evolutionary divergence [106], which is known to generally yield a low success rate [107] and which is further less effective for species that rely on photoperiodic and thermal cues for development [108]. All the above mentioned is associated with reduced ecosystem services and diminished ecological complexity as characteristics of this approach [17]. An additional criticism raised is that the employment of assisted colonization with rare or endangered species (like the Caribbean Acropora species; also, the introduction of pathogens and predators to new locations) poses a great risk for them as well as for the recipient locations [109].

Harnessing the natural phenomenon of coral colonies that raft on floating objects for thousands of kilometers [110], and the natural range expansion of coral species, human intervention through assisted colonization is considered a part of the toolkit of active reef restoration [1,17]. Claims have been made $[63,64]$ that Arabian/Persian Gulf corals, which are already surviving in thermal conditions forecasted to prevail in the future in most tropical reefs, can be considered as a source for assisted migration to the tropical Indo-Pacific. Inter-population hybridizations of gravid colonies adapted to cooler versus warmer temperature areas (such as in the case of Acropora millepora from the Great Barrier 
Reef, Australia [111]) may also be a promising candidate for the assisted migration management of offspring.

\subsection{Assisted Genetics/Evolution}

Assisted evolution/genetics has recently been defined as: "a conservation strategy that involves manipulating the genes of organisms in order to enhance their resilience to climate change and other human impacts" [112]. Assisted evolution/genetics has come to the forefront because climate change has been shown to outpace natural rates of evolution. This may span a wide range of aspects that target either the coral colonies and/or their algal symbionts, including: enhanced coral adaptation; manipulation of algal symbionts to increase coral resistance to bleaching; use of temperature tolerant genotypes to mitigate new environmental challenges; applying interspecific and intraspecific hybridization efforts; using coral nurseries as genetic repositories; and more (Table 1). With regards to the topic of this manuscript, gaining a better understanding of adaptation at the genetic level would clearly benefit coral restoration projects $[113,114]$. Over the short and intermediate terms, corals may adapt to changing environmental conditions by transforming holobiont (coral-algal) properties [65] whereby algal symbiont communities are changed into types/species/clades that enhance the stress tolerance of the host coral. In the long term, changes may occur within the genetic blueprint of the coral colonies, through supportive breeding plans within populations, outcrossing between populations and hybridization between closely related species.

Resulting from the exceptional genetic variability that naturally exists within the endosymbiotic dinoflagellate algae of the family Symbiodiniaceae, much of the assisted evolution/genetics work has been concentrated on manipulating algal species residing within tissues of coral colonies from the same species. This is based on the rationale that seeding less resilient corals with temperature adapted algal variants would provide a management/restoration tool to reduce bleaching and mortality of corals subjected to temperature stress $[67,69,71,113,115]$. However, it must be emphasized that while the literature attests that corals may naturally experience changes in symbiont communities following bleaching episodes, directed manipulations of adult corals in favor of more thermos-tolerant symbionts have only been achieved in the laboratory to date [116].

Following the observation that naturally resilient corals are scarce, genetic manipulation of coral communities under stress conditions is suggested more and more. This includes moving more resilient coral colonies to vulnerable areas within and outside of their species distribution areas, associated with the assisted migration/colonization tenet $[63,64,111,112]$. Another approach is the adoption of breeding programs within populations, outcrossing between populations and hybridizing closely related species [70]. The current research, however, is still at the proof-of-concept stage. While natural hybridization is known in some scleractinian corals, such as the genus Acropora, the applicability of this approach, the fitness of offspring from such outcrossing/hybridization programs in the field, as well as the establishment of successful F2 progenies and their reproductive activities, are all yet to be investigated.

Another assisted genetics/evolution approach is based on the understanding and evidence [81] that coral populations in current reefs embrace a reservoir of alleles preadapted to a wide range of future challenges, such as higher temperatures. This outcome is still poorly documented in measurable parameters and effects. However, the findings point to the potentiality for a rapid evolutionary response to climate change, and the legitimate inclusion of this phenomenon as an efficient restoration tool. This is also connected to the suggestion of using coral nurseries as repositories for genetic material that would have otherwise been lost from reef sites, preserving genotypes for future restoration efforts [66]. All the above mentioned is in addition to the consideration of coral nurseries as applied tools to capture and harvest coral larvae, to increase genetic diversity or to grow mature breeding corals for larval production and the seeding of degraded reefs $[1,17,32,33,44,47,58,97]$. 


\subsection{Assisted Microbiome}

The assisted microbiome tenet, aligned with the assisted genomics/evolution view, is led by the coral probiotic hypothesis [72] for enhancing the adaptation potential of corals to changing environmental conditions through changes in associated bacterial communities. Using this tenet as adaption and restoration tools (Table 1), it has been suggested that microbiome manipulation may alter the coral phenotypes, and subsequently the entire colonies' fitness to withstand environmental challenges [73-75,117].

While at present little is known about the mechanisms related to the "probiotic" protection provided by the coral microbiome, and a key uncertainty exists about the feasibility of manipulating microbes to enhance coral tolerance [73], microbial symbionts were suggested as contributors to the physiology, development, health and immunity of corals, and as a tool to facilitate nutrient cycling and nutrition in general $[116,117]$. Following this rationale, the manipulation of microbiome communities has been suggested as a key strategy to 'engineer' coral phenotypes. However, the ecosystem functioning of bacteria inoculation necessitates further work, as targeted actions are problematic to design without the needed baseline studies [116].

\subsection{Epigenetics}

Organism responses to any environmental challenge develop through either genetic change (e.g., allele frequency alternations between generations, mutational accumulation) and/or nongenetic (i.e., epigenetics) processes. Epigenetics refers to external modifications in genes (e.g., methylation, acetylation, histone modifications and small RNAs; without any modification in gene sequences) that cause change in gene expression. The literature attests that many of the environmentally induced epigenetic changes are, as a matter of fact, heritable [118], thus facilitating the acceleration of adaptation processes.

It is generally assumed that epigenetics allows corals a greater ability to buffer the impacts of environmental changes and of various stress conditions (Table 1), by fine-tuning gene expression, thereby providing additional time for genetic adaptation to occur. A recent study [83] has revealed that epigenetics significantly reduced spurious transcription in the Indo-Pacific coral Stylophora pistillata, diminishing transcriptional noise by fine-tuning gene expressions and causing widespread changes in pathways regulating cell cycle and body size, with impacts on cell and polyp sizes as well as skeletal porosity. In a similar way, probable epigenetic signatures (a) imposed diminished bleaching responses when comparing two of the most severe episodes ( $17 \mathrm{y}$ period) of global-scale seawater temperature anomalies [79], and (b) assisted transplanted gravid coral colonies to release an order of magnitude more coral larvae than local colonies for at least 8 reproductive seasons post transplantation ([46]; unpubl.). Coral epigenetics as a management tool, alleviating impacts of global climate change on reef corals, and as a potential tool for improving reef restoration outcomes, has further gained support from studies showing links between coral adaptation and epigenetics [46,77-83].

Interestingly however, epigenetic changes may also be induced under 'healthy', more pampered situations, such as under parental care and improved nutrition [119-121]. Various epigenetic impacts have already been suggested to develop in coral colonies or coral fragments subject to different environmental conditions $[46,77,83,84]$, most interesting of all are the impacts on heightened long-term coral reproductive capabilities [46]. Thus, favorable biological and physical conditions at the nursery stage, including: optimal light conditions, increased water flow, minimized sedimentation, enhanced planktonic supply, reduced intra- and interspecific competition, and controlled corallivory [15,26-28, $45,58,122]$, may impose lasting epigenetic changes on fitness and on ecological traits of transplanted corals, enhancing their ability to counter global climate change impacts and other less-favorable environmental conditions. It should be noted however that while meriting further experimental investigation, the discipline of epigenetics and epigenetic impacts in corals is still in its infancy. 


\subsection{Coral Chimerism}

A new potential tool in reef restoration (Table 1) that stems from the phenomenon of coral chimerism (Figure 2 [85]). The coral chimera is a biological entity that simultaneously consists of cells originating from at least two sexually-born conspecifics, a natural tissue transplantation phenomenon intermingling complex ecological and evolutionary mechanisms and concepts $[123,124]$. With regards to reef restoration, coral chimerism is presented as one of the best applied tools for accelerating adaptive responses to global climate change impacts [85], thus improving reef restoration tactics. The adaptive qualities are based on the suggestion that coral chimerism counters the erosion of genetic and phenotypic diversity, by presenting high flexibility on somatic constituents following changes in environmental conditions. This enables all partners in a chimera to synergistically present the best-fitting combination of genetic components to the environment $[85,123,124]$. In most cases, chimerism in corals is restricted to specific short windows at early ontogenic stages $[125,126]$ and chimeric impacts are evident from early stages of development [86].

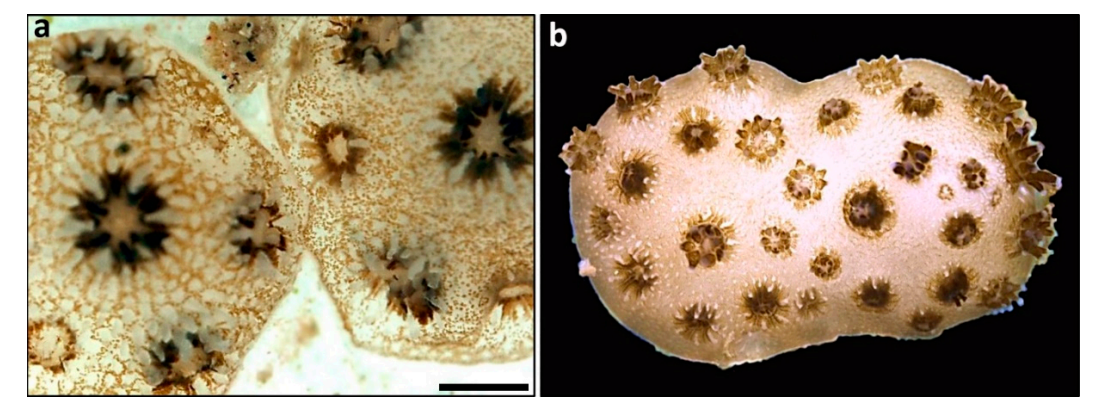

Figure 2. Coral chimerism. (a) Two contacting young spats (about 1 month old) of the Red Sea branching coral Stylophora pistillata, during the process of fusion (bar $=2 \mathrm{~mm}$ ); (b) a several months old chimera of Stylophora pistillata, before the initiation of up-growing branches. Morphologically undistinguished area of fusion.

The literature documents a wide range of ecological advantages and benefits incurred to coral chimeras. Chimerism endows the chimeric entity, primarily at early life-history stages, with an instant survival advantage, like enhanced growth rates by virtue of the abrupt increase in size when the two organisms merge [84,86-88], and facilitation of the healing of exposed coral skeletons by enhanced preferential gregarious settlement of coral planulae [89]. The development of asexual chimeric coral planulae [90] together with the phenomenon of planulae fusion in the water column [88,91] may further mitigate the loss of genetic diversity of small colonizing populations [85,90].

The phenomenon of coral chimerism (Figure 2) is probably one of the least explored potential pathways corals take to buffer the impacts of capricious environmental conditions. Studying coral chimerism is not a trivial task and much has to be investigated before a better understanding can be achieved regarding this unique natural phenomenon and its inclusion in the coral restoration toolbox, another added facet to the gardening approach for active reef restoration [1,17].

\section{Discussion}

Ecological restoration is broadly defined as: 'the process of assisting the recovery of an ecosystem that has been degraded, damaged, or destroyed' [127], and is becoming the major ubiquitous strategy for increasing ecosystem services, as well as for reversing biodiversity decline. As a relatively new discipline it is fraught with hindrances, which is to be expected [128]. In contrast, the science of restoration ecology (primarily the facets that deal with terrestrial ecosystems), has rapidly developed over the past century, maturing into a cohesive body of theory that is backed by an established toolbox of restoration practices. Notwithstanding the growing interest in ecological restoration, the added challenges posed by climate change further reveal that the available adaptation toolkit associated with ecological restoration is still meager [129]. This is also emphasized in the coral restoration arena, a field 
that has not yet developed to the level of scientific maturity comparable to that of terrestrial ecological restoration $[1,17]$.

On top of anthropogenic activities, climate change significantly challenges the concepts, practices and outcomes of ecological restoration. It is now more than a decade since the realization that it makes less sense to establish current restoration approaches on historical references, as they are all under the influence of rapidly changing climate regimes. Although historical references are of interest, they are less useful as ways to establish direct objectives [127]. Furthermore, the forecasted climate change scenarios will pose further challenges, some of which are yet to be experienced. Additionally, restoration efforts will have to address, in addition to restitution of biodiversity and ecosystem services, the ecosystem's resilience in the face of anticipated climate change scenarios [114,130].

This manuscript deals with the currently developing active reef restoration toolbox, used to enhance coral resilience and adaptation in a changing world. Seven classes of avenues and tools were described (Table 1) and discussed, including: the improved gardening methodologies, ecological engineering approaches, assisted migration/colonization, assisted genetics/evolution, assisted microbiome, coral epigenetics and coral chimerism. These tools are further classified into three levels of operation (Figure 3), each is based on the success of the former level, altogether compiling the most current active reef restoration toolbox. This toolbox is based on the rational and methodologies developed for the 'coral gardening' concept [13-19,21,26-28].

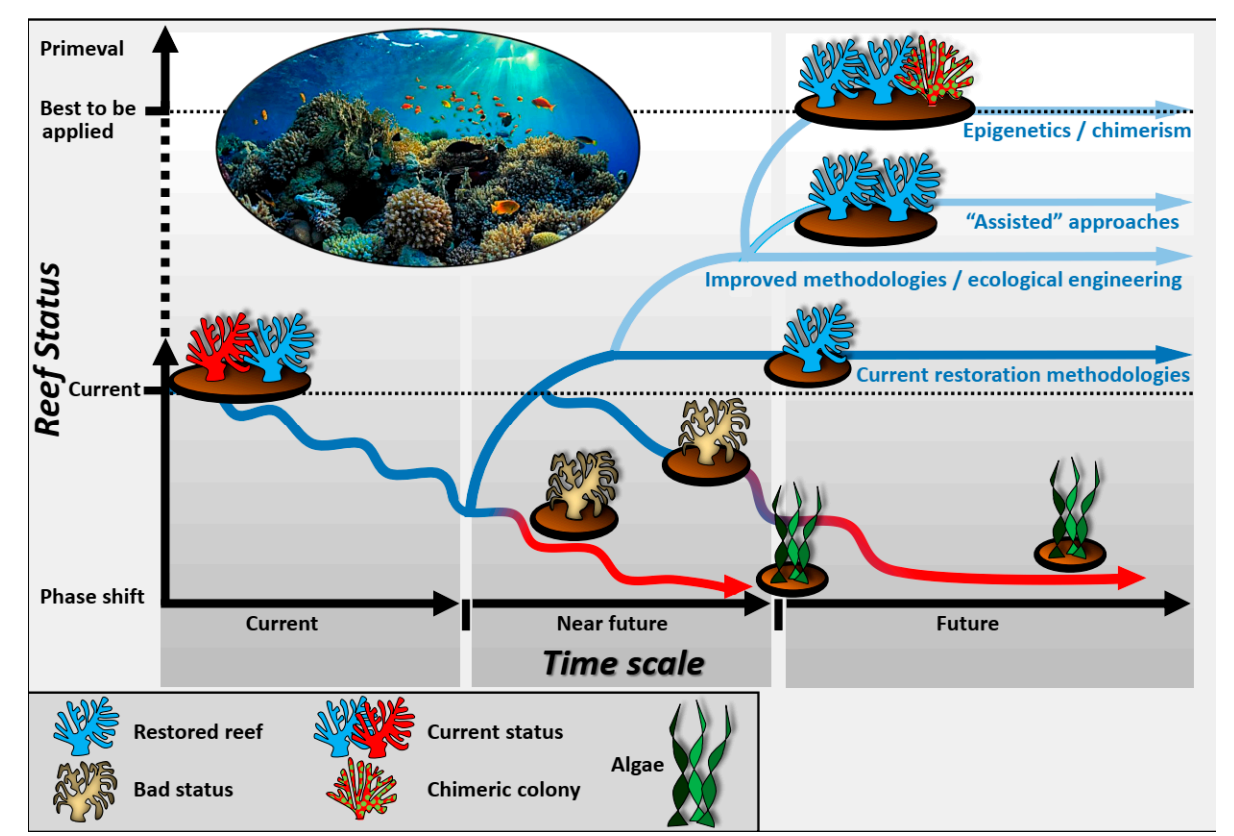

Figure 3. A theoretical illustration depicting how the seven classes of the suggested novel avenues and tools (improved gardening methodologies, ecological engineering approaches, assisted migration/colonization, assisted genetics/evolution, assisted microbiome, coral epigenetics, coral chimerism), further classified into three operation levels, compiling a unified active reef restoration toolbox, under the umbrella of the gardening tenet. Using the currently available restoration methodologies (based on the gardening approach) reef statuses that are anticipated to decline (the red trajectory towards the near future) are improving, or not ([the red trajectory towards the future] depending on the level of stress imposed by anthropogenic activities and climate change drivers). The next evolved level of progress in reef status is achieved by applying improved methodologies and ecological engineering approaches. They may maintain an improved reef status, but not the desirable advanced state. Yet, this level provides the ground for the operational level of 'assisted' approaches and the apex operational level of epigenetics and chimerism approaches, altogether maximizing reef statuses and enhancing coral resilience and adaptation in a changing world, developing to the 'best to be applied' status with current research avenues, yet not approaching the primeval reef status. 
The basic and first level (Figure 3) includes two classes of tools, the improved gardening methodologies and the ecological engineering approaches, which are aimed at further enhancing the efficiency of the coral restoration approach, towards the development of sustainable ecosystems that have human and ecological significance. The research in both classes of coral restoration tools, either on the nursery or the transplantation phases, is highly active, performed in various reefs worldwide on a wide range of coral species, and various new approaches and methodologies are frequently suggested and tested. In addition to maximizing the survival and growth rates of corals in the nursery and after transplantation, the new approaches (primarily the ecological engineering approaches) tackle major issues in reef restoration. These include the phase-shifting of coral reef surfaces from turf algae back to coral dominated layers [60], the creation, within very short time periods, of large coral colonies of ecological importance $[53,59,60]$, and the establishment of new biological corridors through stepping stone mechanisms [17] just to name a few of the ramifying approaches.

The second level (Figure 3) includes the three 'assisted' approaches (assisted migration/colonization, assisted genetics/evolution, and assisted microbiome). This level of operation represents restoration strategies and approaches that shift in theory and in practice from former approaches reliant on reference points and historically based goals, towards a common focus on "process-oriented configurations" [130]. The assisted approaches are still either at a conceptual level, or first laboratory trials, and are challenged by the need to guide the transition towards ecosystem states that can maintain key functions and values in a changing environment. For example, the assisted migration/colonization approach as developed may result in a new ecosystem with reduced services and diminished ecological complexity [17]. The assisted genetics/evolution approach is still at the proof-of-concept stage [116], while the assisted microbiome approach and the suggested activities therein, are still problematic to design as they lack the needed baseline studies [116]. The 'assisted' approaches hinge on successful active restoration methodologies, such as nursery grown colonies and transplantation tactics. It is most likely that much of the 'assisted' approaches will be shaped and intermingled in the future with other ecological engineering approaches to form a toolkit, aimed at achieving an improved ecologically-based restoration strategy. Thus, it is envisaged that neither one of the assisted approaches will stand by itself as an independent restoration strategy.

The third operational level (Figure 3) includes the two approaches of coral epigenetics and coral chimerism. While the success in either approach depends on the rationale and methodologies developed for the 'coral gardening' concept, and on the supplementary ecological engineering toolkit, each approach is based on a well-established biological phenomenon with considerable ecological and evolutionary perspectives. Employing the coral epigenetics tool may provide extra tolerance in case of subsequent re-exposure of the organism (or its progeny) to similar or even harsher conditions. At this stage, most studies on the subject were performed under laboratory conditions or on evaluations of coral responses from the field [77-79,81-83] but there is also documentation for novel phenotypic attributes developed following human manipulation under field conditions (increased growth rates of corals, long term enhancement of reproduction output [46]). Employing the coral chimerism tool may further provide cumulative levels of adaptation, as they are expressed by a naturally occurring phenomenon [84-91,125,126].

Coral chimerism (Figures 2 and 3) has already been discussed as a potential evolutionary rescue instrument, reliant on the premise that it may compensate for the immediate need for genetic change [85]. In a similar way, an epigenetic modification can facilitate evolutionary rescue through the creation of novel phenotypic variants [131]. Thus, both instruments may provide coral populations with the resilience to persist through periods of environmental change. Both instruments, alone or in combination, have the potential to facilitate faster adaptation rates and improved adaptation, than those exhibited in traditional genetic mutations, and thus merit special attention.

It should be noted, however, that risks involved in the application of some of the tools are not yet well defined and that the potential of unknown costs versus perceived benefits assigned to the tools should be evaluated $[106-108,116]$. These include costs for selective breeding that may lead to 
reduced genetic variability, and for increased sensitivity of coral populations to other climate change drivers, the introduction of pathogens and predators via coral transplantation [109], and for the flawed allocation of limited human, institutional and financial resources $[17,116]$. Another topic not addressed here is the scale of future restoration measures at the changing world. While the coral gardening-toolbox could serve as a ubiquitous ecological engineering platform for restoration on a global scale, it is yet facing the most imperative challenge to document restoration manipulations at regional/global levels [17], to determine that the gardening approach indeed supports sustainable coral reefs at large scales. Indeed, results already noted that large-scale coral restoration may have a positive influence on coral survivorship [132], recruitment rates and juvenile density [56]. These acts may further be aided by novel tools, like remote sensing technology [133].

Cumulatively, climate change and anthropogenic impacts pose major challenges for the development of effective tools, not only assessing levels of degradation in reef ecosystems under varying states of alteration, but also for the development of rationales and methodologies to efficiently restore degrading reefs. Based on principles, concepts and theories from silviculture, the "gardening" concept of active reef restoration [13-19,21,26-28] has not only laid the foundation for reef restoration, but is now developing through several seemingly separate approaches (improved gardening methodologies, ecological engineering approaches, assisted migration/colonization, assisted genetics/evolution, assisted microbiome, coral epigenetics and coral chimerism) that are divided here into three operational levels, altogether representing the unified active reef restoration toolbox under the umbrella of the gardening tenet to focus on the development of coral resilience and adaptation in a changing world. This may lead to new policies that will be integrated with other efforts to scale up reef restoration efforts into a global measure embedded within integrated governance structures.

Funding: This research was funded by the AID-MERC program (no M33-001), by the North American Friends of IOLR (NAF/IOLR), by the JNF and by the Israeli-French high council for scientific \& technological research program (Maïmonide-Israel).

Acknowledgments: This study was supported by Thanks are due to G. Paz for drawing Figure 3.

Conflicts of Interest: The author declares no conflicts of interest.

\section{References}

1. Rinkevich, B. Climate change and active reef restoration-Ways of constructing the "reefs of tomorrow". J. Mar. Sci. Eng. 2015, 3, 111-127. [CrossRef]

2. Sully, S.; Burkepile, D.E.; Donovan, M.K.; Hodgson, G.; Van Woesik, R. A global analysis of coral bleaching over the past two decades. Nat. Commun. 2019, 10, 1264. [CrossRef] [PubMed]

3. Jones, K.R.; Klein, C.J.; Halpern, B.S.; Venter, O.; Grantham, H.; Kuempel, C.D.; Shumway, N.; Friedlander, A.M.; Possingham, H.P.; Watson, J.E. The location and protection status of Earth's diminishing marine wilderness. Curr. Biol. 2018, 28, 2506-2512. [CrossRef] [PubMed]

4. Bruno, J.F.; Selig, E.R. Regional decline of coral cover in the Indo-Pacific: Timing, extent, and subregional comparisons. PLoS ONE 2007, 2, e711. [CrossRef] [PubMed]

5. De'ath, G.; Fabricius, K.E.; Sweatman, H.; Puotinen, M. The 27-year decline of coral cover on the great barrier reef and its causes. Proc. Natl. Acad. Sci. USA 2012, 109, 17995-17999. [CrossRef] [PubMed]

6. Trenberth, K.E.; Cheng, L.; Jacobs, P.; Zhang, Y.; Fasullo, J. Hurricane Harvey links to ocean heat content and climate change adaptation. Earths Future 2018, 6, 730-744. [CrossRef]

7. Hughes, T.P.; Kerry, J.T.; Baird, A.H.; Connolly, S.R.; Chase, T.J.; Dietzel, A.; Hill, T.; Hoey, A.S.; Hoogenboom, M.O.; Jacobson, M.; et al. Global warming impairs stock-Recruitment dynamics of corals. Nature 2019, 568, 387-390. [CrossRef] [PubMed]

8. IPCC. Climate Change 2014: Synthesis Report. Contribution of Working Groups I, II and III to the Fifth Assessment Report of the IPCC. In Proccedings of the Intergovernmental Panel on Climate Change; IPCC: Geneva, Switzerland, 2014. 
9. Fong, C.R.; Bittick, S.J.; Fong, P. Simultaneous synergist, antagonistic and additive interactions between multiple local stressors all degrade algal turf communities on coral reefs. J. Ecol. 2018, 106, 1390-1400. [CrossRef]

10. Fine, M.; Cinar, M.; Voolstra, C.R.; Safa, A.; Rinkevich, B.; Laffoley, D.; Hilmi, N.; Allemand, D. Coral reefs of the Red sea-challenges and potential solutions. Reg. Stud. Mar. Sci. 2019, 25, 100498. [CrossRef]

11. Rinkevich, B. Management of coral reefs: We have gone wrong when neglecting active reef restoration. Mar. Pollut. Bull. 2008, 56, 1821-1824. [CrossRef]

12. Miller, K.I.; Russ, G.R. Studies of no-take marine reserves: Methods for differentiating reserve and habitat effects. Ocean Coast. Manag. 2014, 96, 51-60. [CrossRef]

13. Rinkevich, B. Restoration strategies for coral reefs damaged by recreational activities: The use of sexual and asexual recruits. Restor. Ecol. 1995, 3, 241-251. [CrossRef]

14. Rinkevich, B. Steps towards the evaluation of coral reef restoration by using small branch fragments. Mar. Biol. 2000, 136, 807-812. [CrossRef]

15. Rinkevich, B. Conservation of coral reefs through active restoration measures: Recent approaches and last decade progress. Environ. Sci. Technol. 2005, 39, 4333-4342. [CrossRef] [PubMed]

16. Rinkevich, B. The coral gardening concept and the use of underwater nurseries; lesson learned from silvics and silviculture. In Coral Reef Restoration Handbook; Precht, W.F., Ed.; CRC Press: Boca Raton, FL, USA, 2006; pp. 291-301.

17. Rinkevich, B. Rebuilding coral reefs: Does active reef restoration lead to sustainable reefs? Curr. Opin. Environ. Sustain. 2014, 7, 28-36. [CrossRef]

18. Epstein, N.; Bak, R.P.M.; Rinkevich, B. Strategies for gardening denuded coral reef areas: The applicability of using different types of coral material for reef restoration. Restor. Ecol. 2001, 9, 432-442. [CrossRef]

19. Epstein, N.; Bak, R.P.M.; Rinkevich, B. Applying forest restoration principles to coral reef rehabilitation. Aquat. Conserv. 2003, 13, 387-395. [CrossRef]

20. Rinkevich, B. The quandary for active and passive reef restoration in a changing world. In Active Coral Reef Restoration: Techniques for a Changing Planet; Vaughan, D., Ed.; J. Ross Publishing: Fort Lauderdale, FL, USA, in press.

21. Lirman, D.; Schopmeyer, S. Ecological solutions to reef degradation: Optimizing coral reef restoration in the Caribbean and Western Atlantic. Peer J. 2016, 4, e2597. [CrossRef]

22. Bradshaw, A.D. Underlying principles of restoration. Can. J. Fish. Aquat. Sci. 1996, 53 (Suppl. 1), 3-9. [CrossRef]

23. Holl, K.D.; Aide, T.M. When and where to actively restore ecosystems? For. Ecol. Manag. 2011, 261, 1558-1563. [CrossRef]

24. Clewell, A.F.; Aronson, J. Motivations for the restoration of ecosystems. Conserv. Biol. 2006, 20, 420-428. [CrossRef] [PubMed]

25. Shafir, S.; Van Rijn, J.; Rinkevich, B. Steps in the construction of underwater coral nursery, an essential component in reef restoration acts. J. Mar. Biol. 2006, 149, 679-687. [CrossRef]

26. Shafir, S.; van Rijn, J.; Rinkevich, B. A mid-water coral nursery. In Proceedings of the 10th International Coral Reef Symposium, Okinawa, Japan, 28 June-2 July 2004; pp. 1674-1679.

27. Shafir, S.; Rinkevich, B. The underwater silviculture approach for reef restoration: An emergent aquaculture theme. In Aquaculture Research Trends; Schwartz, S.H., Ed.; Nova Science Publications: New York, NY, USA, 2008; pp. 279-295.

28. Shafir, S.; Rinkevich, B. Integrated long term mid-water coral nurseries: A management instrument evolving into a floating ecosystem. Univ. Maurit. Res. J. 2010, 16, 365-379.

29. Shafir, S.; Abady, S.; Rinkevich, B. Improved sustainable maintenance for mid-water coral nursery by the application of an anti-fouling agent. J. Exp. Mar. Biol. Ecol. 2009, 368, 124-128. [CrossRef]

30. Baria, M.V.B.; Guest, J.R.; Edwards, A.J.; Aliño, P.M.; Heyward, A.J.; Gomez, E.D. Caging enhances post-settlement survival of juveniles of the scleractinian coral Acropora tenuis. J. Exp. Mar. Biol. Ecol. 2010, 394, 149-153. [CrossRef]

31. Liñán-Cabello, M.A.; Flores-Ramírez, L.A.; Laurel-Sandoval, M.A.; Mendoza, E.G.; Santiago, O.S.; Delgadillo-Nuño, M.A. Acclimation in Pocillopora spp. during a coral restoration program in Carrizales Bay, Colima, Mexico. Mar. Freshw. Behav. Physiol. 2011, 44, 61-72. [CrossRef] 
32. Linden, B.; Rinkevich, B. Creating stocks of young colonies from brooding-coral larvae, amenable to active reef restoration. J. Exp. Mar. Biol. Ecol. 2011, 398, 40-46. [CrossRef]

33. Linden, B.; Vermeij, M.J.A.; Rinkevich, B. The coral settlement box: A simple device to produce coral stock from brooded coral larvae entirely in situ. Ecol. Eng. 2019, 132, 115-119. [CrossRef]

34. Nakamura, R.; Ando, W.; Yamamoto, H.; Kitano, M.; Sato, A.; Nakamura, M.; Kayanne, H.; Omori, M. Corals mass-cultured from eggs and transplanted as juveniles to their native, remote coral reef. Mar. Ecol. Prog. Ser. 2011, 436, 161-168. [CrossRef]

35. Nedimyer, K.; Gaines, K.; Roach, S. Coral Tree Nursery@: An innovative approach to growing corals in an ocean-based field nursery. Aquac. Aquar. Conserv. Legis. 2011, 4, 442-446.

36. Cooper, W.T.; Lirman, D.; VanGroningen, M.P.; Parkinson, J.E.; Herlan, J.; McManus, J.W. Assessing techniques to enhance early post-settlement survival of corals in situ for reef restoration. Bull. Mar. Sci. 2014, 90, 651-664. [CrossRef]

37. Tebben, J.; Guest, J.R.; Sin, T.M.; Steinberg, P.D.; Harder, T. Corals like it waxed: Paraffin-based antifouling technology enhances coral spat survival. PLoS ONE 2014, 9, e87545. [CrossRef] [PubMed]

38. Toh, T.C.; Ng, C.S.L.; Peh, J.W.K.; Toh, K.B.; Chou, L.M. Augmenting the post-transplantation growth and survivorship of juvenile scleractinian corals via nutritional enhancement. PLoS ONE 2014, 9, e98529. [CrossRef] [PubMed]

39. Horoszowski-Fridman, Y.B.; Brêthes, J.-C.; Rahmani, N.; Rinkevich, B. Marine silviculture: Incorporating ecosystem engineering properties into reef restoration acts. Ecol. Eng. 2015, 82, 201-213. [CrossRef]

40. Chamberland, V.F.; Petersen, D.; Guest, J.R.; Petersen, U.; Brittsan, M.; Vermeij, M.J. New seeding approach reduces costs and time to outplant sexually propagated corals for reef restoration. Sci. Rep. 2017, 7, 18076. [CrossRef] [PubMed]

41. Pollock, F.J.; Katz, S.M.; van de Water, J.A.; Davies, S.W.; Hein, M.; Torda, G.; Matz, M.V.; Beltran, V.H.; Buerger, P.; Puill-Stephan, E.; et al. Coral larvae for restoration and research: A large-scale method for rearing Acropora millepora larvae, inducing settlement, and establishing symbiosis. Peer J. 2017, 5, e3732. [CrossRef] [PubMed]

42. Tagliafico, A.; Rangel, S.; Christidis, L.; Kelaher, B.P. A potential method for improving coral self-attachment. Restor. Ecol. 2018, 26, 1082-1090. [CrossRef]

43. Tagliafico, A.; Rangel, S.; Kelaher, B.; Scheffers, S.; Christidis, L. A new technique to increase polyp production in stony coral aquaculture using waste fragments without polyps. Aquaculture 2018, 484, 303-308. [CrossRef]

44. Zayasu, Y.; Suzuki, G. Comparisons of population density and genetic diversity in artificial and wild populations of an arborescent coral, Acropora yongei: Implications for the efficacy of "artificial spawning hotspots". Restor. Ecol. 2019, 27, 440-446. [CrossRef]

45. Levi, G.; Shaish, L.; Haim, A.; Rinkevich, B. Mid-water rope nursery-Testing design and performance of a novel reef restoration instrument. Ecol. Eng. 2010, 36, 560-569. [CrossRef]

46. Horoszowski-Fridman, Y.B.; Izhaki, I.; Rinkevich, B. Engineering of coral reef larval supply through transplantation of nursery-farmed gravid colonies. J. Exp. Mar. Biol. Ecol. 2011, 399, 162-166. [CrossRef]

47. Horoszowski-Fridman, Y.B.; Rinkevich, B. Restoring the animal forests: Harnessing silviculture biodiversity concepts for coral transplantation. In Marine Animal Forests: The Ecology of Benthic Biodiversity Hotspots; Rossi, S., Bramanti, L., Gori, A., Orejas, C., Eds.; Springer International Publishing: Cham, Switzerland, 2017; pp. 1313-1335.

48. Sabater, M.G.; Yap, H.T. Growth and survival of coral transplants with and without electrochemical deposition of $\mathrm{CaCO}_{3}$. J. Exp. Mar. Biol. Ecol. 2002, 272, 131-146. [CrossRef]

49. Borell, E.M.; Romatzki, S.B.C.; Ferse, S.C.A. Differential physiological responses of two congeneric scleractinian corals to mineral accretion and an electric field. Coral Reef. 2010, 29, 191-200. [CrossRef]

50. Strömberg, S.M.; Lundälv, T.; Goreau, T.J. Suitability of mineral accretion as a rehabilitation method for cold-water coral reefs. J. Exp. Mar. Biol. Ecol. 2010, 395, 153-161. [CrossRef]

51. Ng, C.S.L.; Toh, T.C.; Toh, K.B.; Guest, J.; Chou, L.M. Dietary habits of grazers influence their suitability as biological controls of fouling macroalgae in ex situ mariculture. Aquac. Res. 2014, 45, 1852-1860.

52. Villanueva, R.D.; Baria, M.V.B.; dela Cruz, D.W. Effects of grazing by herbivorous gastropod (Trochus niloticus) on the survivorship of cultured coral Spat. Zool. Stud. 2013, 52, 44. [CrossRef]

53. Forsman, Z.H.; Page, C.A.; Toonen, R.J.; Vaughan, D. Growing coral larger and faster: Micro-colony-fusion as a strategy for accelerating coral cover. Peer J. 2015, 3, e1313. [CrossRef] [PubMed] 
54. Frias-Torres, S.; Van de Geer, C. Testing animal-assisted cleaning prior to transplantation in coral reef restoration. Peer J. 2015, 3, e1287. [CrossRef] [PubMed]

55. Chou, L.M. Rehabilitation engineering of Singapore reefs to cope with urbanization and climate change impacts. JCEA 2016, 10, 932-936.

56. Montoya-Maya, P.H.; Smit, K.P.; Burt, A.J.; Frias-Torres, S. Large-scale coral reef restoration could assist natural recovery in Seychelles, Indian Ocean. J. Nat. Conserv. 2016, 16, 1-17. [CrossRef]

57. Anthony, K.; Bay, L.K.; Costanza, R.; Firn, J.; Gunn, J.; Harrison, P.; Heyward, A.; Lundgren, P.; Mead, D.; Moore, T.; et al. New interventions are needed to save coral reefs. Nat. Ecol. Evol. 2017, 1, 1420-1422. [CrossRef] [PubMed]

58. Linden, B.; Rinkevich, B. Elaborating of an eco-engineering approach for stock enhanced sexually derived coral colonies. J. Exp. Mar. Biol. Ecol. 2017, 486, 314-321. [CrossRef]

59. Page, C.A.; Muller, E.M.; Vaughan, D.E. Microfragmenting for the successful restoration of slow growing massive corals. Ecol. Eng. 2018, 123, 86-94. [CrossRef]

60. Rachmilovitz, E.N.; Rinkevich, B. Tiling the reef-Exploring the first step of an ecological engineering tool that may promote phase-shift reversals in coral reefs. Ecol. Eng. 2017, 105, 150-161. [CrossRef]

61. Knoester, E.G.; Murk, A.J.; Osinga, R. Benefits of herbivorous fish outweigh costs of corallivory in coral nurseries placed close to a Kenyan patch reef. Mar. Ecol. Prog. Ser. 2019, 611, 143-155. [CrossRef]

62. Hoegh-Guldberg, O.; Hughes, L.; McIntyre, S.; Lindenmayer, D.B.; Parmesan, C.; Possingham, H.P.; Thomas, C.D. Assisted colonization and rapid climate change. Science 2008, 321, 345-346. [CrossRef] [PubMed]

63. Coles, S.L.; Riegl, B.M. Thermal tolerances of reef corals in the Gulf: A review of the potential for increasing coral survival and adaptation to climate change through assisted translocation. Mar. Pollut. Bull. 2013, 72, 323-332. [CrossRef] [PubMed]

64. Riegl, B.M.; Purkis, S.J.; Al-Cibahy, A.S.; Abdel-Moati, M.A.; Hoegh-Guldberg, O. Present limits to heat-adaptability in corals and population-level responses to climate extremes. PLoS ONE 2011, 6, e24802. [CrossRef]

65. Baker, A.C. Ecosystems—Reef corals bleach to survive change. Nature 2001, 411, 765-766. [CrossRef]

66. Schopmeyer, S.A.; Lirman, D.; Bartels, E.; Byrne, J.; Gilliam, D.S.; Hunt, J.; Johnson, M.E.; Larson, E.A.; Maxwell, K.; Nedimyer, K.; et al. In situ coral nurseries serve as genetic repositories for coral reef restoration after an extreme cold-water event. Restor. Ecol. 2012, 20, 696-703. [CrossRef]

67. Van Oppen, M.J.; Oliver, J.K.; Putnam, H.M.; Gates, R.D. Building coral reef resilience through assisted evolution. Proc. Natl. Acad. Sci. USA 2015, 112, 2307-2313. [CrossRef] [PubMed]

68. Bay, R.A.; Palumbi, S.R. Multilocus adaptation associated with heat resistance in reef-building corals. Curr. Biol. 2014, 24, 2952-2956. [CrossRef] [PubMed]

69. Chakravarti, L.J.; van Oppen, M.J.H. Experimental evolution in coral photosymbionts as a tool to increase thermal tolerance. Front. Mar. Sci. 2018, 5, 227. [CrossRef]

70. Chan, W.Y.; Peplow, L.M.; Menéndez, P.; Hoffmann, A.A.; van Oppen, M.J. Interspecific hybridization may provide novel opportunities for coral reef restoration. Front. Mar. Sci. 2018, 5, 160. [CrossRef]

71. Quigley, K.M.; Bay, L.K.; Willis, B.L. Leveraging new knowledge of Symbiodinium community regulation in corals for conservation and reef restoration. Mar. Ecol. Prog. Ser. 2018, 600, 245-253. [CrossRef]

72. Reshef, L.; Koren, O.; Loya, Y.; Zilber-Rosenberg, I.; Rosenberg, E. The coral probiotic hypothesis. Environ. Microbiol. 2006, 8, 2068-2073. [CrossRef] [PubMed]

73. Peixoto, R.S.; Rosado, P.M.; Leite, D.C.; Rosado, A.S. Beneficial microorganisms for corals (BMC): Proposed mechanisms for coral health and resilience. Front. Microbiol. 2017, 8, 341. [CrossRef] [PubMed]

74. Epstein, H.E.; Smith, H.A.; Torda, G.; van Oppen, M.J. Microbiome engineering: Enhancing climate resilience in corals. Front. Ecol. Environ. 2019, 17, 100-108. [CrossRef]

75. Rosado, P.M.; Leite, D.C.; Duarte, G.A.; Chaloub, R.M.; Jospin, G.; da Rocha, U.N.; Saraiva, J.P.; Dini-Andreote, F.; Eisen, J.A.; Bourne, D.G.; et al. Marine probiotics: Increasing coral resistance to bleaching through microbiome manipulation. ISME J. 2019, 13, 921-936. [CrossRef]

76. Potts, D.C. Natural-selection in experimental populations of reef-building corals (Scleractinia). Evolution 1984, 38, 1059-1078. [CrossRef]

77. Putnam, H.M.; Gates, R.D. Preconditioning in the reef-building coral Pocillopora damicornis and the potential for trans-generational acclimatization in coral larvae under future climate change conditions. J. Exp. Biol. 2015, 8, 2365-2372. [CrossRef] [PubMed] 
78. Putnam,H.M.; Davidson, J.M.; Gates, R.D. Ocean acidification influences host DNA methylation and phenotypic plasticity in environmentally susceptible corals. Evol. Appl. 2016, 9, 1165-1178. [CrossRef] [PubMed]

79. McClanahan, T.R. Changes in coral sensitivity to thermal anomalies. Mar. Ecol. Prog. Ser. 2017, 570, 71-85. [CrossRef]

80. Dixon, G.B.; Bay, L.K.; Matz, M.V. Bimodal signatures of germline methylation are linked with gene expression plasticity in the coral Acropora millepora. BMC Genomics 2014, 15, 1109.

81. Palumbi, S.R.; Barshis, D.J.; Traylor-Knowles, N.; Bay, R.A. Mechanisms of reef coral resistance to future climate change. Science 2014, 344, 895-898. [CrossRef] [PubMed]

82. Dimond, J.L.; Gamblewood, S.K.; Roberts, S.B. Genetic and epigenetic insight into morphospecies in a reef coral. Mol. Ecol. 2017, 26, 5031-5042. [CrossRef] [PubMed]

83. Liew, Y.J.; Zoccola, D.; Li, Y.; Tambutté, E.; Venn, A.A.; Michell, C.T.; Cui, G.; Deutekom, E.S.; Kaandorp, J.A.; Voolstra, C.R.; et al. Epigenome-associated phenotypic acclimatization to ocean acidification in a reef-building coral. Sci. Adv. 2018, 4, eaar8028. [CrossRef] [PubMed]

84. Raymundo, L.J.; Maypa, A.P. Getting bigger faster: Mediation of size-specific mortality via fusion in juvenile coral transplants. Ecol. Appl. 2004, 14, 281-295. [CrossRef]

85. Rinkevich, B. Coral chimerism as an evolutionary rescue mechanism to mitigate global climate change impacts. Glob. Change Biol. 2019, 25, 1198-1206. [CrossRef] [PubMed]

86. Amar, K.O.; Chadwick, N.E.; Rinkevich, B. Coral kin aggregations exhibit mixed allogeneic reactions and enhanced fitness during early ontogeny. BMC Evol. Biol. 2008, 8, 126. [CrossRef] [PubMed]

87. Puill-Stephan, E.; van Oppen, M.J.H.; Pichavant-Rafini, K.; Willis, B.L. High potential for formation and persistence of chimeras following aggregated larval settlement in the broadcast spawning coral, Acropora millepora. Proc. R. Soc. Lond. Ser. B Biol. Sci. 2012, 279, 699-708. [CrossRef] [PubMed]

88. Mizrahi, D.; Navarrete, S.A.; Flores, A.A.V. Groups travel further: Pelagic metamorphosis and polyp clustering allow higher dispersal potential in sun coral propagules. Coral Reef. 2014, 33, 443-448. [CrossRef]

89. Toh, T.C.; Chou, L.M. Aggregated settlement of Pocillopora damicornis planulae on injury sites may facilitate coral wound healing. Bull. Mar. Sci. 2013, 89, 583-584. [CrossRef]

90. Rinkevich, B.; Shaish, L.; Douek, J.; Ben-Shlomo, R. Venturing in coral larval chimerism: A compact functional domain with fostered genotypic diversity. Sci. Rep. 2016, 6, 19493. [CrossRef] [PubMed]

91. Jiang, L.; Lei, X.M.; Liu, S.; Huang, H. Fused embryos and pre-metamorphic conjoined larvae in a broadcast spawning reef coral. F1000 Res. 2015, 4, 44. [CrossRef]

92. Mitsch, W. When will ecologists learn engineering and engineers learn ecology? Ecol. Eng. 2014, 65, 9-14. [CrossRef]

93. Wild, C.; Hoegh-Guldberg, O.; Naumann, M.S.; Colombo-Pallotta, M.F.; Ateweberhan, M.; Fitt, W.K.; Iglesias-Prieto, R.; Palmer, C.; Bythell, J.C.; Ortiz, J.C.; et al. Climate change impedes scleractinian corals as primary reef ecosystem engineers. Mar. Freshw. Res. 2011, 62, 205-215. [CrossRef]

94. Aronson, J.; Clewell, A.; Moreno-Mateos, D. Ecological restoration and ecological engineering: Complementary or indivisible? Ecol. Eng. 2016, 91, 392-395. [CrossRef]

95. Mitsch, W.J.; Jørgensen, S.E. Ecological Engineering and Ecosystem Restoration; John Wiley \& Sons: Hoboken, NJ, USA, 2004.

96. Poore, A.G.; Graham, S.E.; Byrne, M.; Dworjanyn, S.A. Effects of ocean warming and lowered pH on algal growth and palatability to a grazing gastropod. Mar. Biol. 2016, 163, 99. [CrossRef]

97. Amar, K.O.; Rinkevich, B. A floating mid-water coral nursery as larval dispersion hub: Testing an idea. Mar. Biol. 2007, 151, 713-718. [CrossRef]

98. Shaish, L.; Levy, G.; Katzir, G.; Rinkevich, B. Coral reef restoration (Bolinao, Philippines) in the face of frequent natural catastrophes. Restor. Ecol. 2010, 18, 285-299. [CrossRef]

99. Precht, W.F.; Aronson, R.B. Climate flickers and range shifts of reef corals. Front. Ecol. Environ. 2004, 2, 307-314. [CrossRef]

100. Greenstein, B.J.; Pandolfi, J.M. Escaping the heat: Range shifts of reef coral taxa in coastal Western Australia. Glob. Change Biol. 2008, 14, 513-528. [CrossRef]

101. Yamano, H.; Sugihara, K.; Nomura, K. Rapid poleward range expansion of tropical reef corals in response to rising sea surface temperatures. Geophys. Res. Lett. 2011, 38, L04601. [CrossRef] 
102. Denis, V.; Mezaki, T.; Tanaka, K.; Kuo, C.Y.; De Palmas, S.; Keshavmurthy, S.; Chen, C.A. Coverage, diversity, and functionality of a high-latitude coral community (Tatsukushi, Shikoku Island, Japan). PLoS ONE 2013, 8, e54330. [CrossRef] [PubMed]

103. Baird, A.H.; Sommer, B.; Madin, J.S. Pole-ward range expansion of Acropora spp. along the east coast of Australia. Coral Reef. 2012, 31, 1063. [CrossRef]

104. Tuckett, C.A.; de Bettignies, T.; Fromont, J.; Wernberg, T. Expansion of corals on temperate reefs: Direct and indirect effects of marine heatwaves. Coral Reef. 2017, 36, 947-956. [CrossRef]

105. Muir, P.R.; Wallace, C.C.; Done, T.; Aguirre, J.D. Limited scope for latitudinal extension of reef corals. Science 2015, 348, 1135-1138. [CrossRef] [PubMed]

106. Collyer, M.L.; Heilveil, J.S.; Stockwell, C.A. Contemporary evolutionary divergence for a protected species following assisted colonization. PLoS ONE 2011, 6, e22310. [CrossRef]

107. Chauvenet, A.L.M.; Ewen, J.G.; Armstrong, D.P.; Blackburn, T.M.; Pettorelli, N. Maximizing the success of assisted colonizations. Anim. Conserv. 2013, 16, 161-169. [CrossRef]

108. Wadgymar, S.M.; Cumming, M.N.; Weis, A.E. The success of assisted colonization and assisted gene flow depends on phenology. Glob. Change Biol. 2015, 21, 3786-3799. [CrossRef] [PubMed]

109. Kreyling, J.; Bittner, T.; Jaeschke, A.; Jentsch, A.; Jonas Steinbauer, M.; Thiel, D.; Beierkuhnlein, C. Assisted colonization: A question of focal units and recipient localities. Restor. Ecol. 2011, 19, 433-440. [CrossRef]

110. Jokiel, P.L. Long distance dispersal of reef corals by rafting. Coral Reef. 1984, 3, 113-116. [CrossRef]

111. Van Oppen, M.J.H.; Puill-Stephan, E.; Lundgren, P.; De'ath, G.; Bay, L.K. First-generation fitness consequences of interpopulational hybridisation in a Great Barrier Reef coral and its implications for assisted migration management. Coral Reef. 2014, 33, 607-611. [CrossRef]

112. Filbee-Dexter, K.; Smajdor, A. Ethics of assisted evolution in marine conservation. Front. Mar. Sci. 2019, 6, 20. [CrossRef]

113. Baums, I.B. A restoration genetics guide for coral reef conservation. Mol. Ecol. 2008, 17, 2796-2811. [CrossRef]

114. Raimundo, R.L.; Guimaraes, P.R., Jr.; Evans, D.M. Adaptive networks for restoration ecology. Trends Ecol. Evol. 2018, 33, 664-675. [CrossRef]

115. Levin, R.A.; Voolstra, C.R.; Agrawal, S.; Steinberg, P.D.; Suggett, D.J.; van Oppen, M.J.H. Engineering strategies to decode and enhance the genomes of coral symbionts. Front. Microbiol. 2017, 8, 1220. [CrossRef]

116. National Academies of Sciences, Engineering, and Medicine. A Research Review of Interventions to Increase the Persistence and Resilience of Coral Reefs; The National Academies Press: Washington, DC, USA, 2019.

117. Webster, N.S.; Reusch, T.B. Microbial contributions to the persistence of coral reefs. ISME J. 2017, 11, 2167-2174. [CrossRef]

118. Bošković, A.; Rando, O.J. Transgenerational epigenetic inheritance. Annu. Rev. Genet. 2018, 52, $21-41$. [CrossRef]

119. Cropley, J.E.; Suter, C.M.; Beckman, K.B.; Martin, D.I. Germ-line epigenetic modification of the murine Avy allele by nutritional supplementation. Proc. Natl. Acad. Sci. USA 2006, 103, 17308-17312. [CrossRef] [PubMed]

120. Cooney, C.A.; Dave, A.A.; Wolff, G.L. Maternal methyl supplements in mice affect epigenetic variation and DNA methylation of offspring. J. Nutr. 2002, 132, S2393-S2400. [CrossRef] [PubMed]

121. Champagne, F.A.; Weaver, I.C.; Diorio, J.; Dymov, S.; Szyf, M.; Meaney, M.J. Maternal care associated with methylation of the estrogen receptor- $\alpha 1 \mathrm{~b}$ promoter and estrogen receptor- $\alpha$ expression in the medial preoptic area of female offspring. Endocrinology 2006, 147, 2909-2915. [CrossRef] [PubMed]

122. Bongiorni, L.; Giovanelli, D.; Rinkevich, B.; Pusceddu, A.; Chou, L.M.; Danovaro, R. First step in the restoration of a highly degraded coral reef (Singapore) by in situ coral intensive farming. Aquaculture 2011, 322, 191-200. [CrossRef]

123. Rinkevich, B. Will two walk together, except they have agreed? J. Evol. Biol. 2004, 17, 1178-1179. [CrossRef]

124. Rinkevich, B. Quo vadis chimerism? Chimerism 2011, 2, 1-5. [CrossRef] [PubMed]

125. Frank, U.; Oren, U.; Loya, Y.; Rinkevich, B. Alloimmune maturation in the coral Stylophora pistillata is achieved through three distinctive stages, four months post metamorphosis. Proc. R. Soc. Lond. Ser. B Biol. Sci. 1997, 264, 99-104. [CrossRef]

126. Barki, Y.; Gateño, D.; Graur, D.; Rinkevich, B. Soft-coral natural chimerism: A window in ontogeny allows the creation of entities comprised of incongruous parts. Mar. Ecol. Prog. Ser. 2002, 23, 91-99. [CrossRef] 
127. SER (Society for Ecological). The SER International Primer on Ecological Restoration; Society for Ecological Restoration International: Tucson, AZ, USA, 2006.

128. Hobbs, R.J. Looking for the silver lining: Making the most of failure. Restor. Ecol. 2009, 17, 1-3.

129. Prober, S.M.; Doerr, V.A.; Broadhurst, L.M.; Williams, K.J.; Dickson, F. Shifting the conservation paradigm: A synthesis of options for renovating nature under climate change. Ecol. Monog. 2019, 89, e01333. [CrossRef]

130. Higgs, E.; Falk, D.A.; Guerrini, A.; Hall, M.; Harris, J.; Hobbs, R.J.; Jackson, S.T.; Rhemtulla, J.M.; Throop, W. The changing role of history in restoration ecology. Front. Ecol. Environ. 2014, 12, 499-506. [CrossRef]

131. O’Dea, R.E.; Noble, D.W.; Johnson, S.L.; Hesselson, D.; Nakagawa, S. The role of non-genetic inheritance in evolutionary rescue: Epigenetic buffering, heritable bet hedging and epigenetic traps. Environ. Epigenet. 2016, 2, dvv014. [CrossRef] [PubMed]

132. Williams, S.L.; Sur, C.; Janetski, N.; Hollarsmith, J.A.; Rapi, S.; Barron, L.; Heatwole, S.J.; Yusuf, A.M.; Yusuf, S.; Jompa, J.; et al. Large-scale coral reef rehabilitation after blast fishing in Indonesia. Rest. Ecol. 2019, 27, 447-456. [CrossRef]

133. Foo, S.A.; Asner, G.P. Scaling up coral reef restoration using remote sensing technology. Front. Mar. Sci. 2019, 6, 79. [CrossRef]

(C) 2019 by the author. Licensee MDPI, Basel, Switzerland. This article is an open access article distributed under the terms and conditions of the Creative Commons Attribution (CC BY) license (http://creativecommons.org/licenses/by/4.0/). 